\title{
Article \\ Marker-Assisted Backcrossing (MABc) to Improve Eating Quality with Thin Seed Coat and Aleurone Layer of Non-Glutinous Japonica Variety in Rice
}

\author{
Me-Sun Kim ${ }^{1,+}$, Ju-Kyung Yu ${ }^{2,+}$, Seo-Rin Ko ${ }^{1}$, Ki-Jo Kim ${ }^{1}$, Hyeonso Ji ${ }^{3}$, Kwon-Kyoo Kang ${ }^{4}(\mathbb{D}$ \\ and Yong-Gu Cho $1, *$ (D)
}

1 Department of Crop Science, College of Agriculture and Life \& Environment Sciences, Chungbuk National University, Cheongju 28644, Korea; kimms0121@cbnu.ac.kr (M.-S.K.); seorinko@cbnu.ac.kr (S.-R.K.); kgj2502@gmail.com (K.-J.K.)

2 Syngenta Crop Protection LLC, Seeds Research, 9 Davis Dr. Research Triangle Park, Durham, NC 27709, USA; yjk0830@hotmail.com

3 Department of Agricultural Biotechnology, National Institute of Agricultural Sciences, Rural Development Administration (RDA), Jeonju 54874, Korea; jhs77@korea.kr

4 Division of Horticultural Biotechnology, Hankyong National University, Anseong 17579, Korea; kykang@hknu.ac.kr

* Correspondence: ygcho@cbnu.ac.kr

+ These authors contributed equally to this work.

check for updates

Citation: Kim, M.-S.; Yu, J.-K.; Ko, S.-R.; Kim, K.-J.; Ji, H.; Kang, K.-K.; Cho, Y.-G. Marker-Assisted Backcrossing (MABc) to Improve Eating Quality with Thin Seed Coat and Aleurone Layer of Non-Glutinous Japonica Variety in Rice. Genes 2022, 13, 210. https://doi.org/10.3390/ genes13020210

Academic Editor: Kejian Wang

Received: 31 December 2021

Accepted: 22 January 2022

Published: 24 January 2022

Publisher's Note: MDPI stays neutral with regard to jurisdictional claims in published maps and institutional affiliations.

Copyright: () 2022 by the authors. Licensee MDPI, Basel, Switzerland. This article is an open access article distributed under the terms and conditions of the Creative Commons Attribution (CC BY) license (https:// creativecommons.org/licenses/by/ $4.0 /)$.

\begin{abstract}
Brown rice is composed of rice bran, pericarp, seed coat, and aleurone layers, and the rice bran layer contains a large number of substances useful for the human body, such as dietary fiber, $\alpha$-tocopherol, $\alpha$-tocotrienol, and vitamins. However, more than $90 \%$ of these substances are removed when polished, and white rice has the disadvantage of losing food-related ingredients, such as umami-related amino acids, when compared to the unpolished group. In this study, we tried to develop new breeding lines with a thinner seed coat and aleurone layer to provide high eating quality with softer chewing characteristics and processability in rice grain. We detected an SNP for foreground selection for the backcross population by comparing genome sequences between Samgwang and Seolgaeng and developed high eating quality brown rice breeding lines by applying marker-assisted backcrossing $\left(\mathrm{MAB}_{\mathrm{C}}\right)$ breeding programs to backcross populations between Samgwang and Seolgaeng using KASP markers. SNP markers for foreground selection were identified to improve eating and processability through SNP mapping of Samgwang and Seolgaeng with SSIIa as a target gene in this study. Line selection according to genotype of KASP markers was successful in $\mathrm{BC}_{1} \mathrm{~F}_{1}$ and $\mathrm{BC}_{2} \mathrm{~F}_{1}$ generations, with the recurrent parent genome recovery ratio ranging from $91.22 \%$ to $98.65 \%$. In $\mathrm{BC}_{2} \mathrm{~F}_{1}$ seeds of the selected lines, thickness of the aleurone layer was found to range from 13.82 to $21.67 \mu \mathrm{m}$, which is much thinner than the $30.91 \mu \mathrm{m}$ of the wild type, suggesting that selection by MABc could be used as an additional breeding material for the development of highly processed rice varieties. These lines will be useful to develop new brown rice varieties with softer chewing characteristics and processability in rice grain.
\end{abstract}

Keywords: brown rice; cooking and eating quality; aleurone layer; $\mathrm{MAB}_{\mathrm{C}}$; $\mathrm{SNP}$; KASP marker

\section{Introduction}

Rice (Oryza sativa L.) is a vital, worldwide agricultural product. It is one of the leading food crops of the world, as more than half of the world's population relies on rice as the major daily source of calories and protein [1]. Indeed, the demand for eating quality is continuously increasing around the globe because it is the most important factor in determining the market price [2]. The quality of rice used for eating and the rice yield potential is one of the main goals of rice breeding programs. The main components of rice grain quality include appearance, eating, cooking and milling quality, and nutritional 
qualities, which are all values that are determined by their physiochemical properties and other sociocultural factors [3].

Brown rice consists of 2-3\% embryo, $92 \%$ endosperm, and 5-6\% rice bran, which is composed of pericarp, seed coat, and an aleurone layer. The rice bran layer of brown rice contains dietary fiber and substances such as $\alpha$-tocopherol, $\alpha$-tocotrienol, $\gamma$-tocopherol, $\gamma$-aminobutyric acid (GABA), arabinoxylan, ferulic acid, and vitamins B1 and E. These contain physiologically functional substances such as antidiabetics, antihypertensives, and immune function enhancements, and are found in brown rice relatively more than other grains [4-6]. Brown rice is known to have a beneficial effect on human health because it is a whole-grain cereal. However, more than $90 \%$ of these substances are removed when polished, and white rice has the disadvantage of losing food-related ingredients, such as umami-related amino acids, when compared to the unpolished group [7]. Brown rice is rarely consumed as white rice is preferred for reasons related to appearance, taste, ease of preparation, tradition, safety, shelf life, and lack of awareness of benefits and availability, limiting its market potential [8-10].

'Seolgaeng' is a new japonica variety derived from 'Ilpum' mutant lines that uses treated, fertilized egg cells with N-methyl-N-nitrosourea (MNU) [11]. Seolgaeng is a soft rice with a round starch shape and is suitable as a processing rice, such as for brewing and for producing red yeast rice [12]. Seolgaeng is a non-glutinous rice with an amylose content of $18 \%$ or more, but it is easily crushed. In addition, Seolgaeng is a variety with a low protein content and high free sugar and essential amino acid content; it is mainly used for brewing or for the production of red yeast (Monascus purpureus) rice and yellow koji mold rice (Aspergillus oryzae) [12-14].

Molecular breeding that involves marker-assisted selection (MAS) addresses the limitations of conventional breeding and allows the pyramiding of multiple valuable genes into a single cultivar $[15,16]$. Utilization of DNA markers in a marker-assisted backcrossing $(\mathrm{MABc})$ program significantly increases selection efficiency. The MABc approach avoids complicated issues associated with transgenic technology and conventional breeding methods by developing an ideal genotype in a short time [17-19]. A marker-assisted background selection can recover up to $99 \%$ of the recurrent parent genome in just three backcross cycles, whereas conventional breeding takes more than six backcrosses to recover $99 \%$ of the recurrent parent genome [20]. 'KASP' is a term that stands for Kompitive Allele Specific PCR, a novel competitive allelic PCR for SNP genotype analysis based on dual Fluorescent Resonance Energy Transfer (FRET). KASP is widely used for genetic mapping and trait-specific marker development such as rice genotype analysis, wheat leaf rust resistance analysis, and soybean cyst nematode resistance study; it is low-cost with high reliability and reproducibility [21-23].

In this study, we tried to develop new breeding lines with a thinner seed coat and aleurone layer to provide high eating quality with softer chewing characteristics and processability in rice grain by applying MABc breeding programs to backcross populations between Samgwang and Seolgaeng using KASP markers.

\section{Materials and Methods}

\subsection{Plant Materials, Rice Cultivation, and Sample Preparation}

In this study, rice varieties Samgwang [24] and Seolgang [11] were used as parents for developing a backcross population, and Koshihikari and Keunun were used as check varieties. They were cultivated and harvested according to a standard cultivation method of the Rural Development Administration (RDA) in Korea [25] in an experimental paddy field at Chungbuk National University in 2019-2021. Seeds were dried until a moisture content of $14 \%$ and we removed the hulls using a roller husking machine, and then brown rice was polished using a polishing machine (MC-90A, Toyoseiki, Tokyo, Japan) to a degree of grinding rate of $90 \%$. Fifteen grams of polished rice were made of rice flour using a 100-mesh screen by Cyclotec Sample Mill (Tecator Co., Höganäs, Sweden), which was used for viscosity analysis. 


\subsection{MABc Breeding Strategy}

Samgwang, an excellent variety cultivated in a wide area in Korea, was used as a female parent and crossed with Seolgaeng as a male parent to develop $F_{1}$ generation in an experimental paddy field at Chungbuk National University in 2019. $F_{1}$ plants were backcrossed to Samgwang for $\mathrm{BC}_{1} \mathrm{~F}_{1}$ generation. Consecutive backcrossing was conducted until $\mathrm{BC}_{2} \mathrm{~F}_{1}$ generation was produced from 2019 to 2020 . KASP markers were applied to each generation for background selection. Out of a total of 210 individuals in $\mathrm{BC}_{1} \mathrm{~F}_{1}$, 96 plants were selected through the foreground selection. The genetic background of those 96 individuals was screened, and six selected individuals were progressed to the $\mathrm{BC}_{2} \mathrm{~F}_{1}$ population. The $\mathrm{BC}_{2} \mathrm{~F}_{1}$ population was developed in the experimental paddy field, and their phenotype was observed through agronomic trait analysis. As in $\mathrm{BC}_{2} \mathrm{~F}_{1}, 15$ individuals were selected through foreground and background selection in $\mathrm{BC}_{2} \mathrm{~F}_{2}$. Then, $15 \mathrm{BC}_{2} \mathrm{~F}_{2}$ seeds were used to investigate characteristics related to eating quality.

\subsection{Evaluation of Cooking and Pasting Characteristics}

\subsubsection{Analysis of Amylose and Protein Contents, Whiteness}

Amylose content and protein content and whiteness (an indicator of the whiteness of grains of rice) were measured using the Infratec 1241 Grain Analyzer (FOSS, Hilleroed, Denmark) and were investigated in three replicates for each treatment [26]. Near-infrared spectroscopy is a device that detects the content of components such as carbohydrates, protein, fat, and moisture by measuring absorbance using electromagnetic waves $(780-2500 \mathrm{~nm})$. This instrument has the advantage of being fast and non-destructive because it is simple to use and measures several components simultaneously [27].

\subsubsection{Characterizations of Cooking and Eating Texture}

Thirty grams of milled rice samples were cooked for $30 \mathrm{~min}$ and cooled down for 25 min using a cooler. Ten grams of cooked milled rice were placed on an experimental plate and used for investigating cooking taste characteristics by a full cup method [28]. Each experiment was conducted in three replicates. A TensiPresser Analyzer (My Boy, TAKETOMO Electric Inc., Tokyo, Japan) was used to investigate cooking and eating quality and to measure hardness, adhesiveness, springiness, stickiness, and thickness.

\subsubsection{Rapid Visco Analysis (RVA)}

Three grams of rice flour with $25 \mathrm{~mL}$ of distilled water were blended in an aluminum can and transferred to a Rapid Viscosity Analyzer (Model RVA-4, Newport Scientific Ltd., Warriewood, Australia). Analysis conditions for RVA were set to be started at $50{ }^{\circ} \mathrm{C}$ for one minute and heated to $95^{\circ} \mathrm{C}$ at the rate of $12{ }^{\circ} \mathrm{C}$ per min. Then, the temperature was set to remain at $95{ }^{\circ} \mathrm{C}$ for two min and cool down to $50{ }^{\circ} \mathrm{C}$ for $7 \mathrm{~min}$. Each experiment was conducted in three replicates. Six paste viscosity properties were derived through this process, denoted as PV (peak viscosity, RVU), HPV (hot paste viscosity, RVU), CPV (cool paste viscosity, RVU), Breakdown (highest viscosity-lowest viscosity, RVU), Setback (cool paste viscosity-highest viscosity, RVU), and GT (gelatinization temperature, ${ }^{\circ} \mathrm{C}$ ).

\subsection{Molecular Marker Analysis}

\subsubsection{Foreground Selection Using Semi-Nested PCR Analysis}

Whole genome re-sequencing analysis of Samgwang and Seolgaeng was performed using HiSeq 2500 Sequencing System (Illumina, San Diego, CA, USA), and short-read sequences obtained from the genome re-sequencing data were aligned through the Bowtie program. Assembly and mapping were performed using CLC Main Workbench Software (QIAGEN, Hilden, Germany). Mutation analysis was performed by comparison with reference rice genome sequence of IRSGP1.0 (International Rice Genome Sequencing Project). Foreground selection markers were designed at ranges up to $1000 \mathrm{bp}$, including the mutant region of the OsSSIIa gene. To select individuals with target genotypes, DNA was extracted 
from leaves of Samgwang/Seolgaeng $\mathrm{BC}_{1} \mathrm{~F}_{1}$ and $\mathrm{BC}_{2} \mathrm{~F}_{1}$ populations and deep-sequencing was performed based on semi-nested PCR using the method described by Chi et al. [29].

\subsubsection{Background Selection Using KASP Marker Analysis}

In order to detect SNPs between Korean Japonica rice cultivars, 773 KASP markers were used to select lines with high recurrent parent genome recovery ratios for $\mathrm{BC}_{1} \mathrm{~F}_{1}$ and $\mathrm{BC}_{2} \mathrm{~F}_{1}$ populations between Samgwang and Seolgaeng [30]. For analysis using KASP markers, polymorphisms of Samgwang and Seolgaeng were investigated through Seed Industry Promotion Center of Foundation of Agri. Tech. Commercialization and Transfer (FACT) (Gimje, Korea). Among 386 KASP markers showing polymorphism, markers showing hetero genotypes were excluded, and 96 markers located at $5 \mathrm{Mb}$ intervals per 12 chromosomes in rice were selected to analyze the recurrent parent genome recovery ratios in $\mathrm{BC}_{1} \mathrm{~F}_{1}$ and $\mathrm{BC}_{2} \mathrm{~F}_{1}$ of Samgwang/Seolgaeng. A genetic graphic map was derived using a MapChart program (version 2.32) based on the physical locations of the KASP markers on chromosomes [31].

\subsubsection{Investigation of Agronomic Traits}

Agronomic characteristics such as plant height, culm length, panicle length, and number of tillers in the lines selected from the $\mathrm{BC}_{1} \mathrm{~F}_{1}, \mathrm{BC}_{2} \mathrm{~F}_{1}$, and $\mathrm{BC}_{2} \mathrm{~F}_{2}$ generations were investigated for phenotypes according to a standard method of RDA, Korea [25]. Using the $15 \mathrm{BC}_{2} \mathrm{~F}_{2}$ lines that show a recovery rate of $97-99.1 \%$ of the recurrent parent genome, paste viscosity characteristics were investigated as an eating quality-related trait. Each experiment was conducted in three replicates.

\subsection{Histological Study}

Histological analysis of seed coat and aleurone layer structures were performed according to Carlo and Marco [32]. Immature seeds were collected 18 days after flowering on plants. Each experiment was conducted in three replicates. Collected samples were fixed in FAA (formalin-acetic acid-ethanol) for $48 \mathrm{~h}$. Then, samples were dehydrated in a graded series of ethanol $(60 \%, 70 \%, 80 \%, 90 \%, 95 \%$, and $100 \%)$ for 30 min each and embedded in paraffin wax. Embedded samples were cut into $20 \mu \mathrm{m}$ sections and were stained using $0.5 \%$ periodic acid and Schiff reagent. After staining, seed coat and aleurone layers structures were examined using an Eclipce E600 microscope (Nikon, Tokyo, Japan).

\subsection{Statistics Analysis}

SAS program (SAS Institute Inc., Cary, NC, USA) was used for statistical analysis of the investigated cooking and eating quality traits. Basic statistics such as mean and standard deviation were analyzed according to the collected data, and the distribution of variance was investigated. Significance $(p<0.05)$ was analyzed using analysis of variance, and significant differences were compared and analyzed by performing Duncan's Multiple Range Test.

\section{Results}

\subsection{Evaluation of Characteristics Related to Eating and Cooking Quality in Parents}

Samgwang is a variety with high yield and high quality and is one of the most popular in Korea [33]. Seolgaeng is an excellent rice variety that consumers use as a brown rice. Compared to white rice, brown rice is rich in nutrients such as protein, dietary fiber, and vitamins, so it is highly preferred by consumers as a health functional food. However, the rice bran layer is thicker than that of white rice and the texture of the rice is somewhat rough because moisture absorption is poor due to the difference in structural characteristics [11,12]. Prior to using Samgwang and Seolgang as experimental materials, cooking and texture characteristics, amylose content, protein content, whiteness, and viscosity characteristics were investigated to compare eating quality-related characteristics of Samgwang and Seolgaeng. At the same time, considering that Samgwang is a white rice 
variety and Seolgaeng is a brown rice variety, they were compared with Koshihikari and Keunnun, respectively.

\subsubsection{Characteristics Related to Cooking and Texture}

Table 1 shows the cooking and texture characteristics of Samgwang, Koshihikari, Seolgaeng, and Keunnun. Hardness is the force required to compress the rice when chewing, and the higher it is, the harder the texture is evaluated. The hardness levels of Samgwang and Koshihikari were measured at 36.03 and 31.75, compared to those of Seolgaeng and Keunnun, which were 38.43 and 37.33, respectively. The white rice variety is expected to have a lower hardness than the brown rice variety, causing it to be softer to chew. Adhesiveness is the tenacity of the rice. Koshihikari (71.92) had higher adhesiveness than Samgwang (64.69), and Seolgaeng (53.02) had higher adhesiveness than Keunnun (52.09). Springiness refers to the degree to which a grain of rice returns when pressed but not completely broken. Koshihikari (34.56) was higher in springiness than Samgwang (30.92), and Seolgaeng (37.48) was the highest among the four varieties. As for stickiness, Koshihikari (75.10) was measured as higher than Samgwang (68.73), and Seolgaeng was 56.89, which was higher than Keunnun (47.32).

Table 1. Characteristics of texture and eating quality in Samgwang, Koshihikari, Seolgaeng, and Keunnun.

\begin{tabular}{ccccc}
\hline Variety & Hardness & Adhesiveness & Springiness & Stickiness \\
\hline Samgwang & $36.03 \pm 0.26^{\S}$ & $64.69 \pm 11.75$ & $30.92 \pm 0.94$ & $68.73 \pm 8.25$ \\
Koshihikari & $31.75 \pm 5.73$ & $71.92 \pm 14.79$ & $34.56 \pm 4.26$ & $75.10 \pm 9.91$ \\
Seolgaeng & $38.43 \pm 2.81$ & $53.02 \pm 6.84$ & $37.48 \pm 3.18$ & $56.89 \pm 8.68$ \\
Keunnun & $37.33 \pm 5.29$ & $52.09 \pm 8.59$ & $23.62 \pm 3.96$ & $47.32 \pm 13.38$ \\
\hline F-value & 1.494 & 2.301 & $9.577^{* *}$ & $4.357^{*}$
\end{tabular}

${ }^{*} p<0.05 ;{ }^{* *} p<0.01$. ${ }^{\S}$ Each test was performed in three replicates and values are expressed as average \pm standard deviation.

\subsubsection{Characteristics Related to Eating Quality}

Eating quality-related characteristics such as amylose content, protein content, and whiteness of Samgwang, Koshihikari, Seolgaeng, and Keunnun are shown in Figure 1. Amylose content of all four varieties was within the range of amylose content in nonglutinous rice for cooking (18-20\%), but it was found that the amylose content was rather high at $19.3 \%$ in Seolgaeng. It is known that the protein content of rice is inversely proportional to the taste of rice during cooking and proportional to its viscosity. In addition, the higher the protein content, the more transparent and harder the rice grains are, so it takes more water and time to cook [34]. Protein content of the four varieties was similar to that of japonica rice at 5.91-7.89\% [35], and there was no significant difference between the varieties. Whiteness is an indicator of the phenotype of rice grain, with Seolgaeng showing the highest value at 55\%, followed by Koshihikari at 44.6\%, Keunnun at 43.1\%, and Samgwang at $31.5 \%$. 


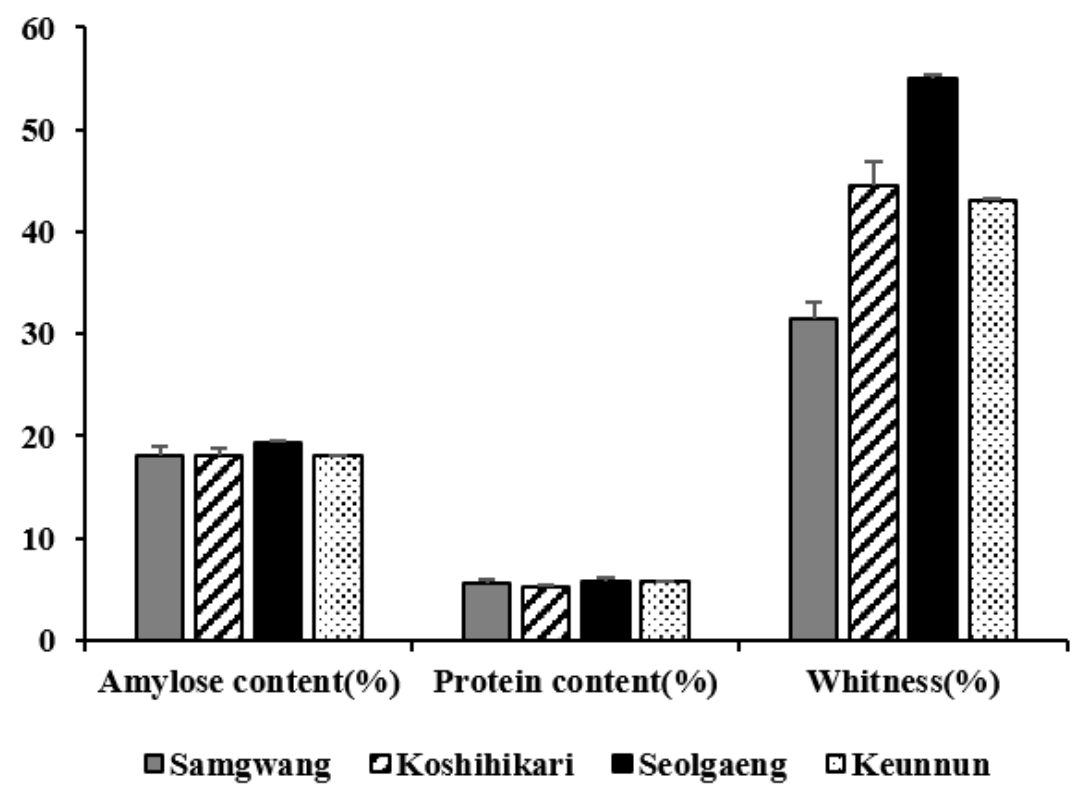

Figure 1. Comparison of amylose content, protein content, and whiteness, which are related to eating quality in four Korean rice varieties. Each experiment was performed in three replicates.

\subsubsection{Viscosity Characteristics by RVA}

When starch is heated above gelatinization temperature with sufficient water, starch particles absorb water and swell, thereby increasing the volume and viscosity [36]. Gelatinization initiation temperature is the minimum temperature required for gelatinization and the temperature at which the viscosity starts to increase. Varieties with a high gelatinization temperature require a lot of water and time to cook, and consumers prefer varieties with a lower temperature [37]. When comparing the gelatinization temperatures of the four varieties, Samgwang, Koshihikari, and Keunnun, having similar amylose content showed similar gelatinization temperatures, and Seolgaeng showed a higher gelatinization temperature (Table 2). In general, rice with a high amylose content has a higher gelatinization initiation temperature because the starch structure is denser [33,38]. High viscosity indicates the water capacity of starch, and the higher the peak viscosity, the weaker the gel is that is forms. Samgwang showed a higher viscosity than other varieties, and it is estimated that it will be softer when gelatinized. If the starch is continuously heated after reaching the highest viscosity, the amylose that was forming the starch particles is dissolved and the starch particles break, thereby reaching the lowest viscosity at which viscosity decreases. Breakdown viscosity, which is the difference between peak viscosity and hot paste viscosity, is related to the stability of processing, and the lower the value, the stronger the resistance to heat and shear of gel, which is considered favorable for processing [39]. The breakdown viscosity was shown in order of Samgwang, Koshihikari, Seolgaeng, and Keunnun, indicating that Seolgaeng and Keunnun are the most suitable for processing. This is also consistent with the report that Seolgaeng and Keunnun are used for brewing and for the production of germinated brown rice $[40,41]$. When the gelatinized starch is cooled, the eluted amylose molecules are entangled to form a network structure, and the empty space is also filled with broken starch particles, thereby increasing viscosity as the structure hardens. The maximum recorded viscosity is called final viscosity or cool paste viscosity. The higher the amylose content, the faster the structure is formed, so the cool paste viscosity increases [42]. Samgwang and Koshihikari showed similar cool paste viscosity, and the processing varieties Seolgaeng and Keunnun showed similar cool paste viscosity. Although the highest amylose content was in Seolgaeng, Keunnun showed the highest cool paste viscosity, suggesting that aging occurs long after cooking. Setback viscosity is the value obtained by subtracting the peak viscosity from the cool paste viscosity, and the higher the value of setback viscosity, the faster the starch aging occurs [39]. The 
order of setback viscosity from highest to lowest was Keunnun, Seolgaeng, Koshihikari, and Samgwang; therefore, it is thought that Samgwang has the slowest aging and Keunnun has the fastest aging.

Table 2. Pasting properties in Samgwang, Koshihikari, Seolgaeng, and Keunnun.

\begin{tabular}{ccccccc}
\hline \multirow{2}{*}{ Variety } & \multicolumn{3}{c}{ Viscosity (RVU) } & \multicolumn{2}{c}{ GT $\int$} \\
\cline { 2 - 7 } & PV & HPV ${ }^{\mathbb{I}}$ & Breakdown & CPV $^{+}$ & Setback & $\left.{ }^{\circ} \mathbf{C}\right)$ \\
\hline Samgwang & $296.42 \pm 4.92 \int$ & $170.86 \pm 6.74$ & $125.56 \pm 18.86$ & $253.21 \pm 9.33$ & $-43.21 \pm 13.73$ & $69.73 \pm 0.45$ \\
Koshihikari & $264.38 \pm 9.32$ & $160.70 \pm 15.18$ & $103.68 \pm 11.46$ & $252.03 \pm 11.71$ & $-12.35 \pm 9.44$ & $70.67 \pm 1.19$ \\
Seolgaeng & $251.89 \pm 5.01$ & $159.94 \pm 2.76$ & $91.95 \pm 2.46$ & $260.22 \pm 3.43$ & $8.33 \pm 1.92$ & $72.13 \pm 0.43$ \\
Keunnun & $226.42 \pm 2.06$ & $154.61 \pm 4.67$ & $71.81 \pm 3.56$ & $263.92 \pm 3.85$ & $37.50 \pm 1.91$ & $70.92 \pm 0.36$ \\
\hline$F$-value & $14.253^{* *}$ & $6.997^{*}$ & 2.988 & $6.449^{*}$ & $14.647^{*}$ & $55.057^{* * *}$ \\
\hline
\end{tabular}

$\S \mathrm{PV}$, peak viscosity; ${ }^{\text {II }} \mathrm{HPV}$, hot paste viscosity; ${ }^{\dagger} \mathrm{CPV}$, cool paste viscosity; $\int \mathrm{GT}$, gelatinization temperature. ${ }^{*} p<0.05 ;{ }^{* *} p<0.01 ; * * * 0.001$. $\int$ Each test was performed in three replicates and values are expressed as average \pm standard deviation.

\subsection{Whole-Genome Re-Sequencing Analysis and Variant Discovery for Foreground Selection}

\subsubsection{Foreground Selection in $\mathrm{BC}_{1} \mathrm{~F}_{1}$ and $\mathrm{BC}_{2} \mathrm{~F}_{1}$}

Using SNP found in the SSIIa gene region between Samgwang and Seolgaeng, NGS analysis was performed to select lines with the SSIIa genotype of Seolgaeng from the $\mathrm{BC}_{1} \mathrm{~F}_{1}$ and $\mathrm{BC}_{2} \mathrm{~F}_{1}$ populations. The structure of the SSIIa gene showing the mutation between Samgwang and Seolgaeng and the location and amino acid mutation of the discovered SNP are shown in Figure 2A. Two PCRs were performed to confirm the target SNP. The PCR test was performed by synthesizing the first primer having a size of $782 \mathrm{bp}$, including the target SNP position in the SSIIa gene. Then, PCR was performed on the first PCR product by designing a second primer having a size of $276 \mathrm{bp}$ (Figure 2B). After confirming the presence of the PCR band by electrophoresis, NGS analysis was performed on $\mathrm{BC}_{1} \mathrm{~F}_{1}(210)$ and $\mathrm{BC}_{2} \mathrm{~F}_{1}$ (96) individuals. As a result, it was confirmed that 100 individuals in $\mathrm{BC}_{1} \mathrm{~F}_{1}$ and 55 individuals in $\mathrm{BC}_{2} \mathrm{~F}_{1}$ had the SNP type of SSIla as heterozygosity (G/A). Finally, it was confirmed that the separation ratio was 1:1 in $\mathrm{BC}_{1} \mathrm{~F}_{1}$ and $\mathrm{BC}_{2} \mathrm{~F}_{1}$ generations. Therefore, background selection analysis was performed on these selected individuals (Table 3 ).

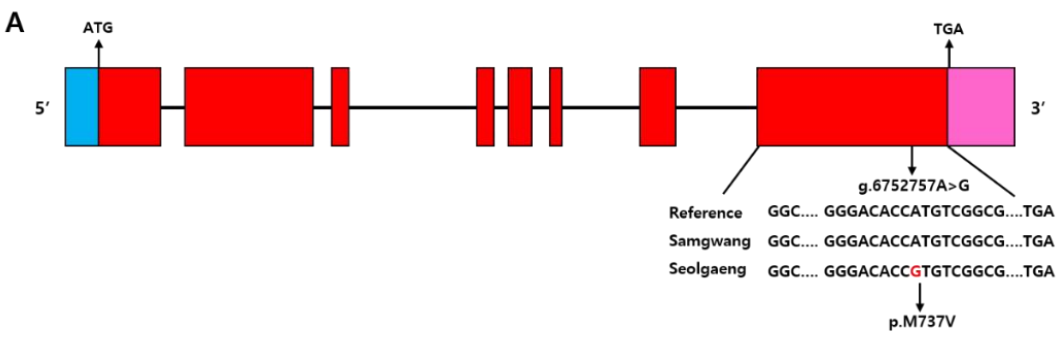

B

ATG.........TGGACGTGCACCTGCAGTCCGACGGCTACGCCAACTACACCGTGGCCTCGCTGGACTCCAGCAAGCC GCGGTGCAAGGCGGCGCTGCAGCGCGAGCTGGGGCTGGAGGTGCGCGACGACGTGCCGCTGATCGGGTTCATCGG GCGGCTCGACGGGCAGAAAGGTGTGGACATCATCGGCGACGCGATGCCGTGGATCGCCGGGCAGGACGTGCAGCT GGTGCTGCTGGGCTCCGGCCGCCGCGACCTGGAGGTGATGCTGCAGCGGTTCGAGGCGCAGCACAACAGCAAGGT GCGCGGGTGGGTGGGGTTCTCGGTGAAGATGGCGCACCGGATCACGGCGGGCGCCGACGTGCTGGTCATGCCGTC GCGGTTCGAGCCGTGCGGCCTCAACCAGCTCTACGCCATGGCGTACGGCACCGTCCCCGTCGTGCACGCCGTCGG CGGGCTGAGGGRCACCATGICGGCGITCGRCCCGITCGRGGACACCGGCCTCGGGTGGACGITCGACCGCGCCGA

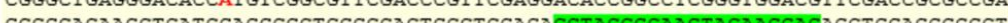
CCCGCACAACTCATCGAGCGCTCGGCCACTGCCTCGRGACGTACCGCAAGIACAAGGAGAGCTGGAGGGGCI CAAGTACCAATGGTGAAGAGACCATGTCCGCCCGCGGTCTCCGCCTGCGCGTTCGGCAGCTATAGCTATAGCCTC CCTGAAGAAGCTTGGCGCTGCTGTGGAGGTGCGACTCGGTGGCGGTGTGGCGCCGGCGCCGGCGCTTGCAGGGGA GGTGTTIGTGCTGACCGAGCTGIGCGTIGAGGTGCGCAAATTAGCTICCGGTTIGTGTGT........ATT

Figure 2. Structure of SSIIa gene contained SNP location and amino acid substitution. (A) SNP loci(A/G) showing missense non-synonymous amino acid substitution [Methionine(M) to Valine(V): p.M737V] in 8th exon of SSIIa gene. Blue box, upstream; red box, CDS; pink box, downstream. (B) Positions and information of 1st and 2nd PCR primer sets and SNP (red color) used for foreground selection in CDS region of SSIIa gene; 1st PCR primer set is yellow color, 2nd PCR primer set is green color. 
Table 3. Statistical analysis for genotyping results through foreground selection with 210 backcross population $\left(\mathrm{BC}_{1} \mathrm{~F}_{1}\right)$ and 96 backcross population $\left(\mathrm{BC}_{2} \mathrm{~F}_{1}\right)$ from the cross between Samgwang and Seolgaeng.

\begin{tabular}{|c|c|c|c|c|c|}
\hline \multirow{2}{*}{ Population } & \multirow{2}{*}{ Generation } & \multicolumn{3}{|c|}{ Number of Plant } & \multirow{2}{*}{$\underset{(1: 1)}{\chi^{2} \text { Value }}$} \\
\hline & & Total & Homo (A/A) & Hetero (A/G) & \\
\hline Samgwang $\times$ Seolgaeng & $\begin{array}{l}\mathrm{BC}_{1} \mathrm{~F}_{1} \\
\mathrm{BC}_{2} \mathrm{~F}_{1}\end{array}$ & $\begin{array}{l}210 \\
96\end{array}$ & $\begin{array}{c}110 \\
41\end{array}$ & $\begin{array}{l}100 \\
55\end{array}$ & $\begin{array}{l}0.48 \\
2.04\end{array}$ \\
\hline
\end{tabular}

\subsubsection{Background Selection in $\mathrm{BC}_{1} \mathrm{~F}_{1}$ and $\mathrm{BC}_{2} \mathrm{~F}_{1}$}

Prior to the selection of individuals with a high recurrent parent genome recovery ratio in the $\mathrm{BC}_{1} \mathrm{~F}_{1}$ and $\mathrm{BC}_{2} \mathrm{~F}_{1}$ populations of Samgwang and Seolgang, the KASP marker validity test as a background selection marker for Samgwang and Seolgang was performed. Among 773 KASP markers developed to detect SNPs between japonica rice varieties, a total of 397 KASP markers were found to distinguish genotypes of Samgwang and Seolgaeng, excluding markers that were not amplified or that showed heterozygote genotypes. Among these, the final 96 KASP markers were selected at about $5 \mathrm{Mb}$ intervals for each chromosome to be evenly distributed in 12 rice chromosomes (Figure 3). Using the final selected 96 KASP markers, genotyping analysis was performed on $96 \mathrm{BC}_{1} \mathrm{~F}_{1}$ (Figure $4 \mathrm{~A}$ ) and $55 \mathrm{BC}_{2} \mathrm{~F}_{1}$ (Figure 5A) individuals from Samgwang and Seolgaeng chosen in foreground selection, respectively. As a result of analyzing the recovery ratio of the recurrent parent genome of 96 individuals of Samgwang and Seolgaeng $\mathrm{BC}_{1} \mathrm{~F}_{1}$ and based on the genotyping results, most of them showed a range of $60 \%$ to $65 \%$, and seven individuals showed a recovery ratio of $75 \%$ or more. Among the individuals with a recurrent parent genome recovery ratio in the range of $75 \%$ or more, seven $\mathrm{BC}_{1} \mathrm{~F}_{1}$ lines with excellent phenotypes were selected (Figure 4B). Table 4 shows the results of the investigation of plant height, culm length, panicle length, and number of tillers. SS007 showed the highest number of tillers, SS045 showed the longest length, and SS100 was confirmed to have the longest plant length. The selected $\mathrm{BC}_{1} \mathrm{~F}_{1}$ individuals were crossed with Samgwang to produce the next $\mathrm{BC}_{2} \mathrm{~F}_{1}$ backcross generation (Figure $5 \mathrm{~B}$ ). As a result of agriculture traits analysis of $\mathrm{BC}_{2} \mathrm{~F}_{1}$ individuals of Samgwang and Seolgaeng, all six $\mathrm{BC}_{2} \mathrm{~F}_{1}$ individuals exhibited shorter panicle length than those of Samgwang, but plant height and culm length showed similar levels to Samgwang. Therefore, it is estimated that individuals with a high recurrent parent genome recovery ratio will exhibit excellent yield due to having a large number of tillers while showing a phenotype similar to Samgwang (Table 5).
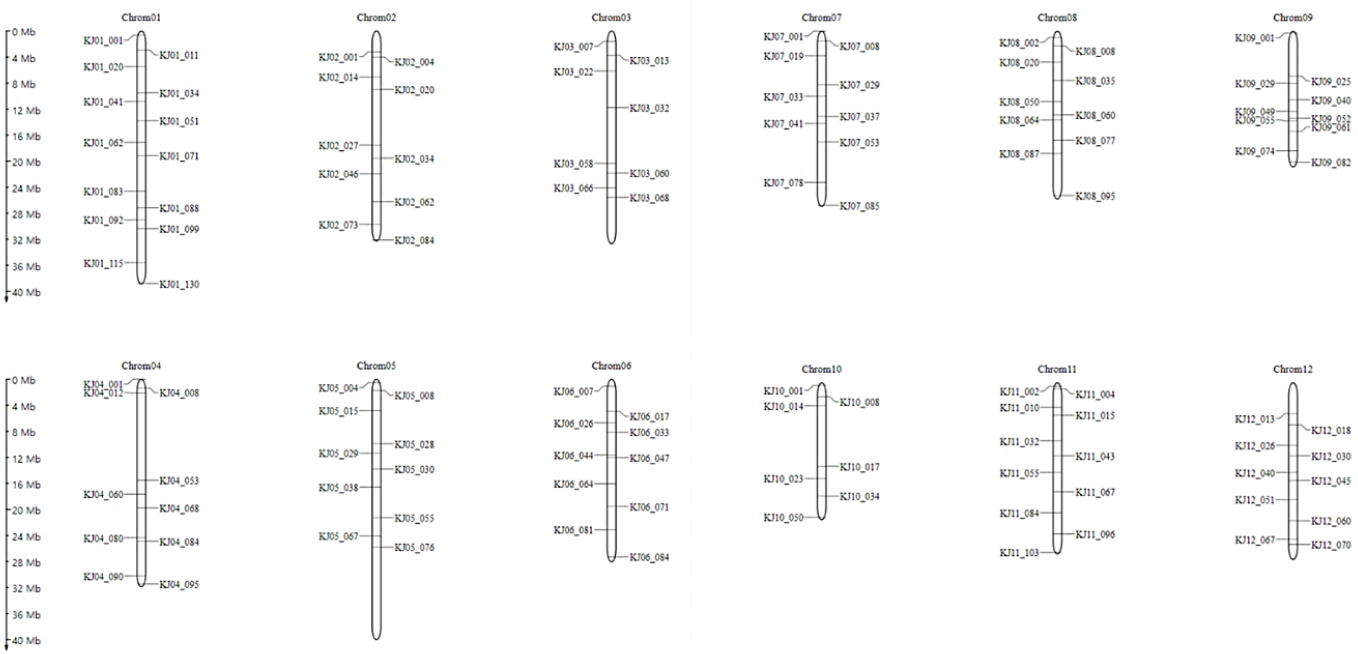

Figure 3. Chromosomal locations of 96 KASP markers indicating SNP polymorphism between Samgwang and Seolgaeng marked at approximately $5 \mathrm{Mb}$ intervals on each chromosome for background selection. 
A
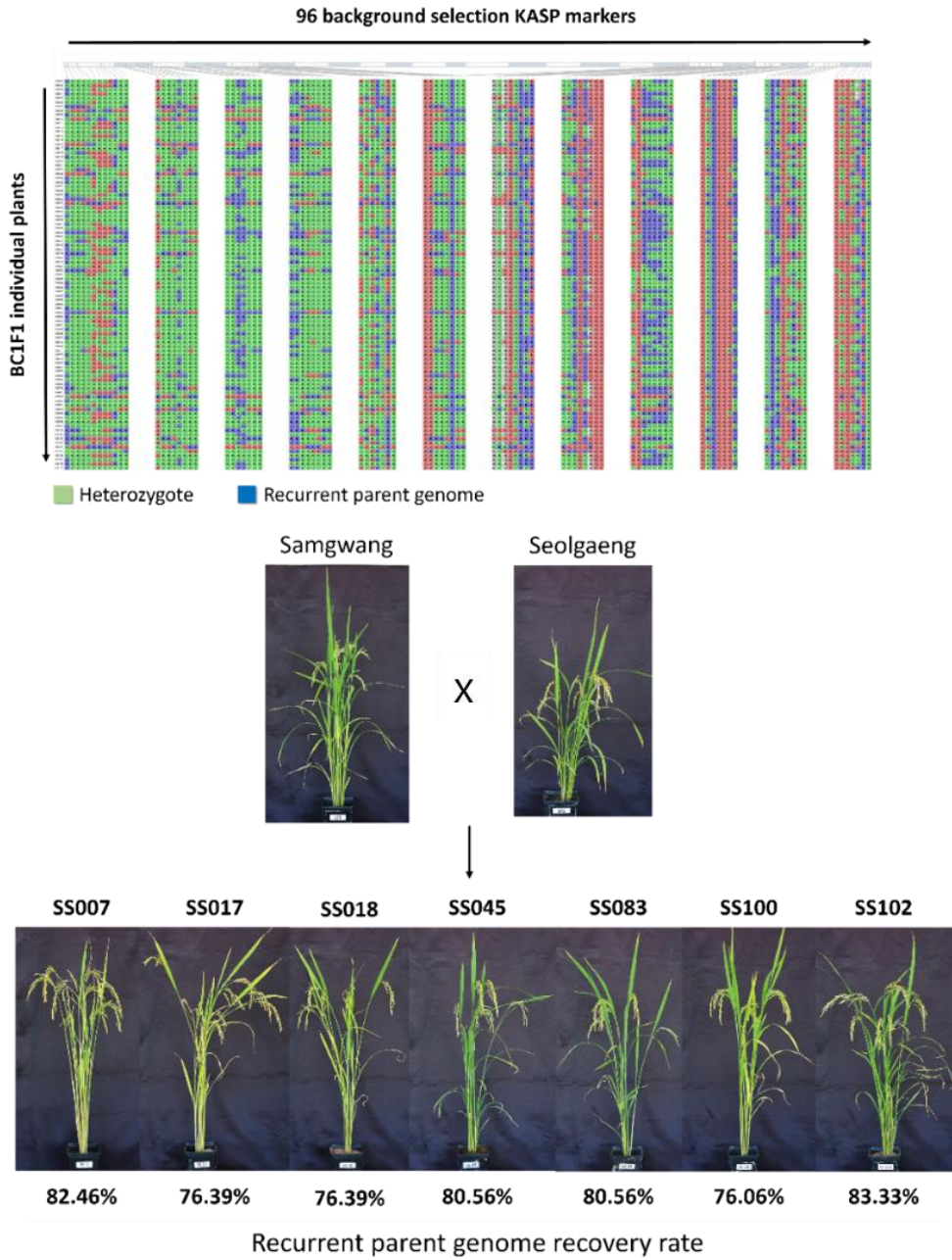

Figure 4. (A) Genotyping results using $96 \mathrm{KASP}$ markers for the $\mathrm{BC}_{1} \mathrm{~F}_{1}$ population of a total of 93 individuals. (B) Phenotype observation of seven $\mathrm{BC}_{1} \mathrm{~F}_{1}$ lines with high genome recovery rates for recurrent parent, Samgwang.

Table 4. Analysis of agronomic traits comparing the selected $\mathrm{BC}_{1} \mathrm{~F}_{1}$ lines and parents, respectively.

\begin{tabular}{cccccc}
\hline Population & Line & Plant Height $\mathbf{( c m )}$ & Culm Length $(\mathbf{c m})$ & Panicle Length $(\mathbf{c m})$ & No. of Tillers \\
\hline \multirow{2}{*}{ Parent } & Samgwang $\$$ & $95.2 \pm 4.6$ & $64.8 \pm 6.0$ & $19.7 \pm 1.5$ & $9 \pm 1$ \\
& Seolgaeng & $82.0 \pm 5.8$ & $51.0 \pm 3.3$ & $19.6 \pm 1.2$ & $7 \pm 2$ \\
\hline & SS007 & 94.2 & 70.8 & 19.2 & 13 \\
& SS017 & 102.0 & 79.4 & 78.8 & 8 \\
$\mathrm{BC}_{1} \mathrm{~F}_{1}$ & SS018 & 94.2 & 73.8 & 2.0 & 6 \\
& SS045 & 99.4 & 63.0 & 20.0 & 6 \\
& SS083 & 95.6 & 73.6 & 20.8 & 6 \\
\hline
\end{tabular}

$\S$ Each test in parent variety was performed in three replicates and values are expressed as average \pm standard deviation. 
A

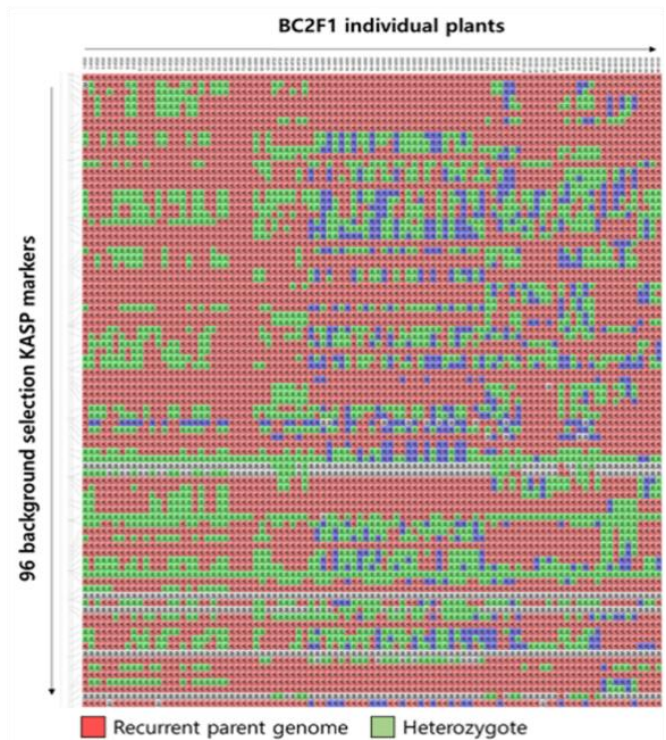

B

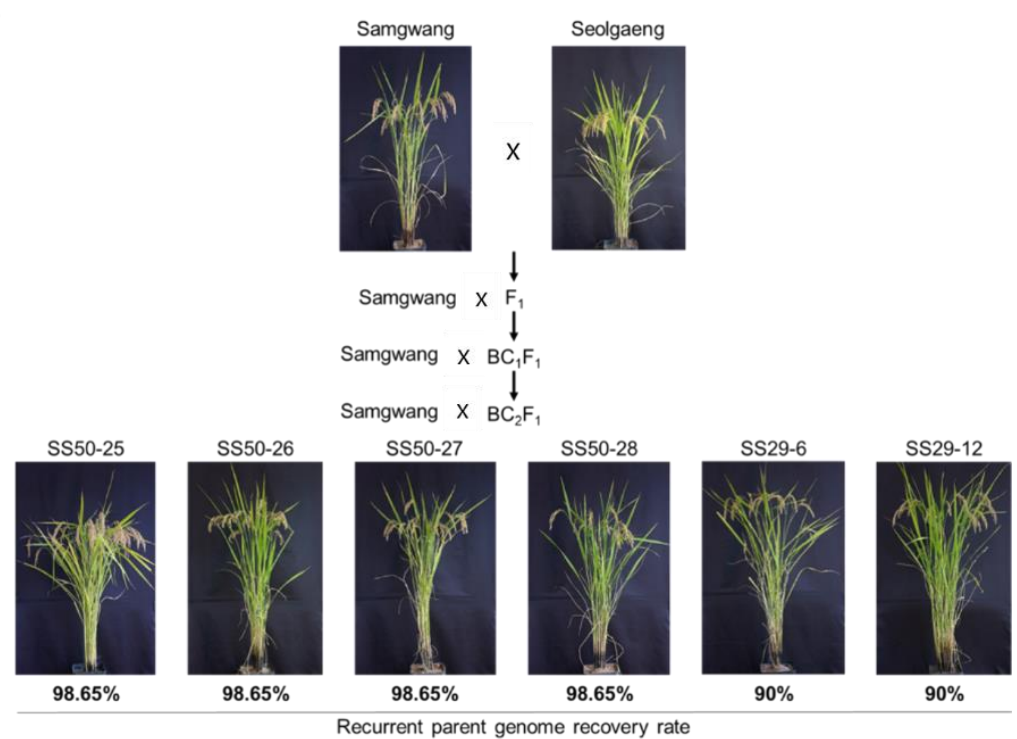

Figure 5. (A) Genotyping results of $93 \mathrm{BC}_{2} \mathrm{~F}_{1}$ plants using $96 \mathrm{KASP}$ markers for background selection in the backcross population between Samgwang and Seolgaeng. (B) Phenotype observation of six $\mathrm{BC}_{2} \mathrm{~F}_{1}$ lines with high genome recovery rates for recurrent parent, Samgwang.

Table 5. Analysis of agronomic traits comparing the selected $\mathrm{BC}_{2} \mathrm{~F}_{1}$ lines and parents, respectively.

\begin{tabular}{cccccc}
\hline Population & Line & Plant Height $(\mathbf{c m})$ & Culm Length $(\mathbf{c m})$ & Panicle Length $(\mathbf{c m})$ & No. of Tillers \\
\hline \multirow{2}{*}{ Parent } & Samgwang & $112.3 \pm 4.4 \S$ & $85.6 \pm 2.1$ & $21.9 \pm 7.5$ & $10.3 \pm 2$ \\
& Seolgaeng & $116.2 \pm 8.5$ & $83.1 \pm 3.4$ & $19.1 \pm 3.7$ & $10.3 \pm 3$ \\
\hline & SS50-25 & 118.0 & 85.9 & 16.0 & 18 \\
$\mathrm{BC}_{2} \mathrm{~F}_{1}$ & SS50-26 & 116.8 & 92.8 & 18.2 & 14 \\
& SS50-27 & 118.3 & 86.7 & 17.4 & 10 \\
& SS50-28 & 117.5 & 83.6 & 19.1 & 10 \\
& SS29-06 & 111.5 & 89.7 & 19.5 & 17 \\
\hline
\end{tabular}

$\S$ Each test in parent variety was performed in three replicates and values are expressed as average \pm standard deviation.

\subsection{Viscosity Properties of the Selected Lines in $B C_{2} F_{2}$}

Characteristics of paste viscosity were investigated for 15 lines, including the selected lines, whose target SNP of the SSIIa gene had a Seolgaeng genotype and whose genome recovery ratio of Samgwang was $98 \%$ or higher (Table 6). Gelatinization initiation temperature of 15 lines showed a similar trend overall. Peak viscosity of nine lines (SS20-04, SS29-25, SS29-26, SS29-11, SS29-12, SS50-25, SS50-26, SS50-27, and SS50-28) was higher than Samgwang, and breakdown viscosity similar to Samgwang was found in eight lines. Cool paste viscosity was found between Samgwang and Seolgaeng, and the lowest viscosity of setback viscosity was found in SS29-26 and the highest in SS50-03. Nine $\mathrm{BC}_{2} \mathrm{~F}_{2}$ lines, which have higher peak viscosity than Samgwang, have a high cool paste viscosity, meaning they are expected to form a soft gel during gelatinization. In addition, all 15 lines are expected to show cool paste viscosity similar to Samgwang, which is expected to cause rapid aging of starch; however, some lines with higher setback viscosity than Samgwang, such as SS50-26, are expected to show lower setback viscosity, resulting in higher processing stability and slower aging of starch. 
Table 6. Analysis of viscosity properties, comparing selected $\mathrm{BC}_{2} \mathrm{~F}_{2}$ lines and parents.

\begin{tabular}{|c|c|c|c|c|c|c|c|c|c|c|c|c|}
\hline \multirow{3}{*}{ Population } & \multicolumn{10}{|c|}{ Viscosity (RVU) } & \multirow{2}{*}{\multicolumn{2}{|c|}{$\mathrm{GT} \int\left({ }^{\circ} \mathrm{C}\right)$}} \\
\hline & \multicolumn{2}{|l|}{$\mathbf{P V} \S$} & \multicolumn{2}{|l|}{$\mathrm{HPV}^{\mathbb{T}}$} & \multicolumn{2}{|l|}{ Breakdown } & \multicolumn{2}{|c|}{$\mathrm{CPV}^{+}$} & \multicolumn{2}{|c|}{ Setback } & & \\
\hline & Mean \pm SD & $t$ & Mean \pm SD & $t$ & Mean \pm SD & $t$ & Mean \pm SD & $t$ & Mean \pm SD & $t$ & Mean \pm SD & $t$ \\
\hline $\begin{array}{l}\text { Samgwang } \\
\text { Seolgaeng }\end{array}$ & $\begin{array}{c}235.2 \pm 15.1 \S \\
223.1 \pm 19.5\end{array}$ & 0.85 & $\begin{array}{c}139.1 \pm 9.8 \\
138.3 \pm 13.9\end{array}$ & 0.079 & $\begin{array}{l}120.3 \pm 18.3 \\
110.1 \pm 11.2\end{array}$ & 0.831 & $\begin{array}{l}219 . \pm 16.1 \\
165.7 \pm 2.9\end{array}$ & $5.179 * *$ & $\begin{array}{l}-22.6 \pm 1.3 \\
-20.4 \pm 0.7\end{array}$ & -2.478 & $\begin{array}{l}69.7 \pm 1.0 \\
72.1 \pm 0.7\end{array}$ & -3.471 * \\
\hline $\begin{array}{l}\text { SS29-01 } \\
\text { SS20-02 } \\
\text { SS29-03 } \\
\text { SS29-04 } \\
\text { SS29-05 } \\
\text { SS29-06 } \\
\text { SS29-11 } \\
\text { SS29-12 } \\
\text { SS29-21 } \\
\text { SS29-22 } \\
\text { SS50-20 } \\
\text { SS50-25 } \\
\text { SS50-26 } \\
\text { SS50-27 } \\
\text { SS50-28 }\end{array}$ & $\begin{array}{l}205.75 \\
217.59 \\
203.79 \\
235.96 \\
256.50 \\
247.25 \\
246.67 \\
242.79 \\
234.75 \\
229.88 \\
213.46 \\
241.42 \\
251.67 \\
252.25 \\
238.88\end{array}$ & & $\begin{array}{l}118.58 \\
126.92 \\
122.71 \\
144.29 \\
144.75 \\
124.84 \\
144.16 \\
129.83 \\
139.58 \\
131.96 \\
139.84 \\
138.42 \\
130.88 \\
135.42 \\
128.38\end{array}$ & & $\begin{array}{c}87.17 \\
90.67 \\
81.08 \\
91.67 \\
111.75 \\
122.42 \\
102.50 \\
112.96 \\
95.17 \\
97.92 \\
73.63 \\
103.00 \\
120.79 \\
116.84 \\
110.00\end{array}$ & & $\begin{array}{l}196 \\
206 \\
202 \\
227 \\
231 \\
218 \\
228 \\
220 \\
224 \\
213 \\
225 \\
221 \\
215 \\
216 \\
217\end{array}$ & & $\begin{array}{c}-9.00 \\
-11.21 \\
-1.71 \\
-8.29 \\
-25.00 \\
-28.7 \\
-17.92 \\
-22.37 \\
-10.7 \\
-16.13 \\
11.71 \\
-19.8 \\
-36.67 \\
-35.3 \\
-21.21\end{array}$ & & $\begin{array}{l}72 . \\
72.8 \\
72 . \\
71 . \\
72 . \\
70 . \\
72.5 \\
70.6 \\
72 . \\
71 . \\
72 . \\
72.5 \\
72 . \\
72 . \\
72 .\end{array}$ & \\
\hline$F$-value & $37.93^{* * *}$ & & $27.46^{* *}$ & & $78.19^{* * *}$ & & 29.81 & & $88.80 * *$ & & 19.09 & \\
\hline
\end{tabular}

\subsection{Histochemical Analysis of Seed Coat and Aleurone Layers in $B C_{2} F_{1}$}

For the histological analysis of seed coat and aleurone layer thickness of Samgwang and Seolgaeng, 18 DAF seeds were cut with a microtome, and tissue staining by carbohydrate staining was performed (Figure 6). As a result, it was confirmed that the thickness of the aleurone layer in Samgwang was $30.91 \mu \mathrm{m}$, which was thicker than the aleurone layer in Seolgaeng that was measured at $11.93 \mu \mathrm{m}$. As a result of performing histological analysis using a microtome on four $\mathrm{BC}_{2} \mathrm{~F}_{1}$ seeds with the highest recurrent parent genome recovery ratio, it was confirmed that they had similar seed coat and aleurone layer thickness to Seolgaeng, with high eating quality and processable brown rice variety characteristics (Figure 7). Therefore, four $\mathrm{BC}_{2} \mathrm{~F}_{1}$ lines (SS50-25, SS50-26, SS50-27, and SS50-28) with a high recurrent parent genome recovery ratio and similar seed coat and aleurone layer thicknesses to Seolgaeng among $\mathrm{BC}_{2} \mathrm{~F}_{1}$ cultivated in this study can be used as excellent breeding materials with improved eating quality and processability.

A

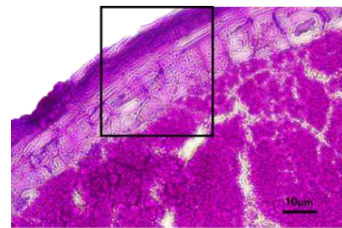

c

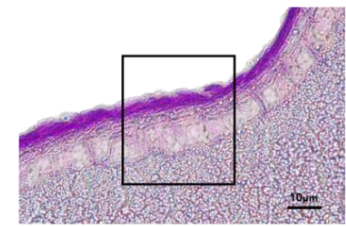

E

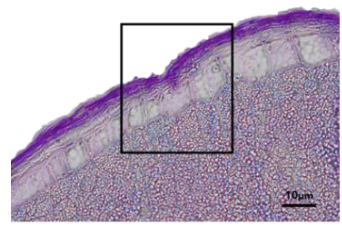

B

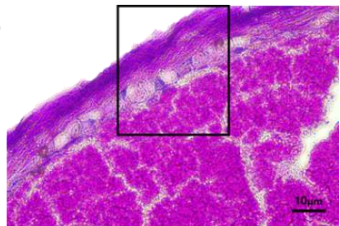

D

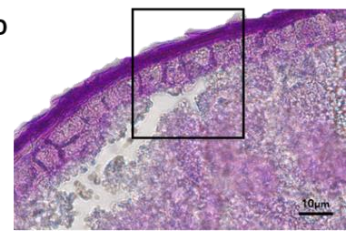

$\mathbf{F}$

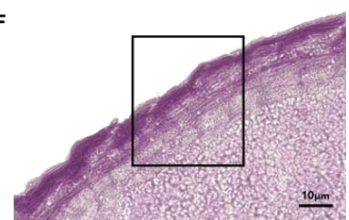

Figure 6. Histological observation of seed coat and aleurone layers in the selected $\mathrm{BC}_{2} \mathrm{~F}_{1}$ grains compared with Samgwang and Seolgaeng. The square box indicates region of seed coat and aleurone layer investigated in this study. (A): Samgwang $(30.91 \mu \mathrm{m}),(\mathbf{B})$ : Seolgaeng $(11.83 \mu \mathrm{m}),(\mathbf{C})$ : SS50-25

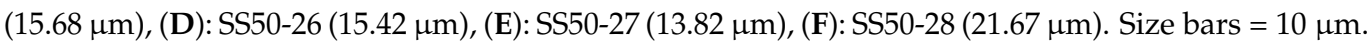




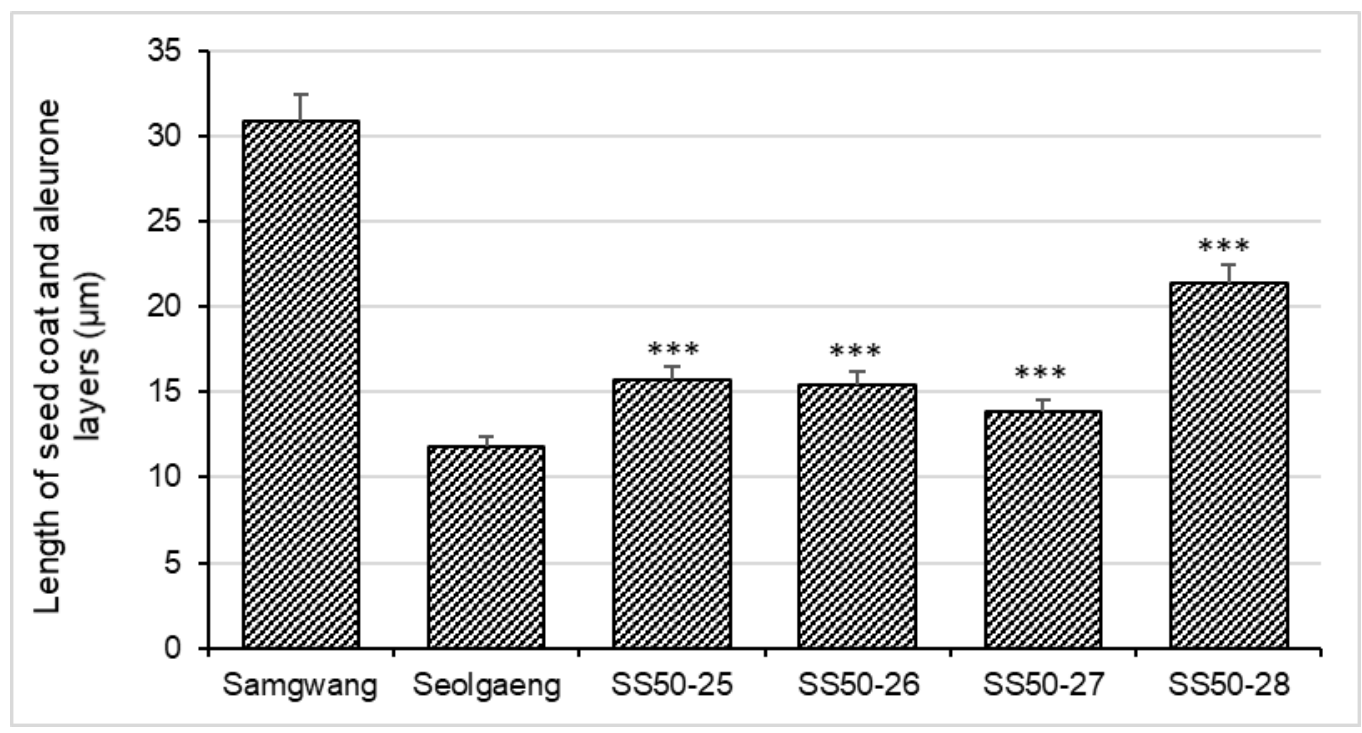

Figure 7. Length of seed coat and aleurone layers of selected lines in comparison with parents. Each experiment was performed in three replicates. ${ }^{* * *}: p<0.001$.

\subsection{Agronomic Traits of the Selected Lines in $\mathrm{BC}_{2} \mathrm{~F}_{2}$}

The selected and improved $\mathrm{BC}_{2} \mathrm{~F}_{2}$ lines were evaluated based on agriculture characteristics and the results were compared to the phenotype of their recurrent parent, Samgwang (Figure 8). Plant height ranged from $104.8 \mathrm{~cm}$ to $112.8 \mathrm{~cm}$, which was similar to the plant height of Samgwang, the recurrent parent variety. Culm length was $85.0 \mathrm{~cm}$ to $94.5 \mathrm{~cm}$, similar to the $88.7 \mathrm{~cm}$ of Samgwang. The lines were also similar to Samgwang in panicle length and number of tillers (Table 7). Therefore, it was confirmed that $\mathrm{BC}_{2} \mathrm{~F}_{2}$ lines with high recurrent parent genome recovery ratios showed a similar phenotype to Samgwang.

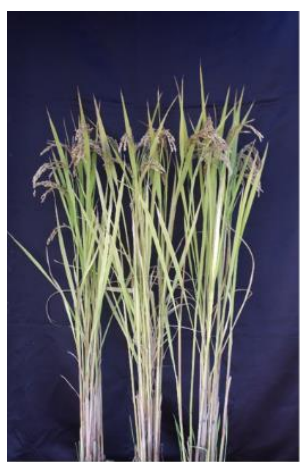

SS50-25

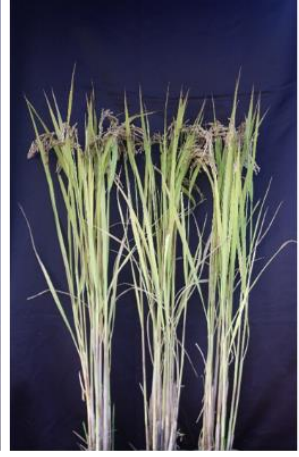

SS50-26

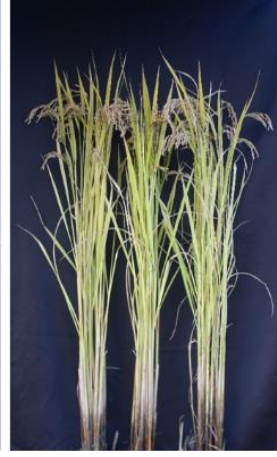

SS50-27

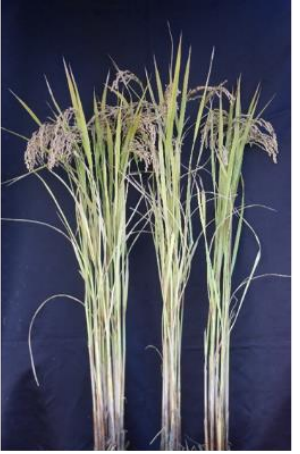

SS50-28

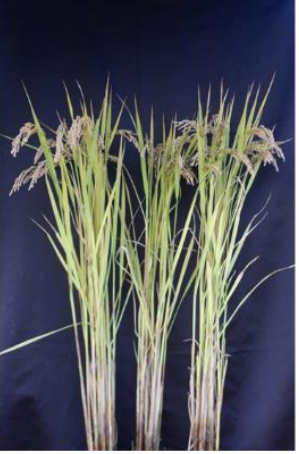

SS29-06

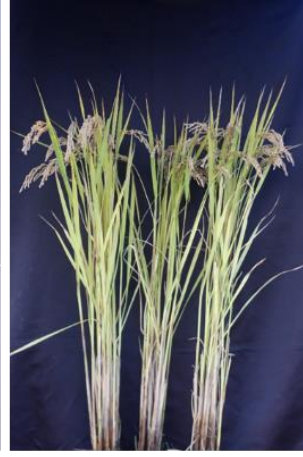

SS29-12

Figure 8. Observation of phenotypes of $\mathrm{BC}_{2} \mathrm{~F}_{2}$ lines advanced in rice paddy field. 
Table 7. Analysis of agronomic traits comparing the selected $\mathrm{BC}_{2} \mathrm{~F}_{2}$ lines and parents, respectively.

\begin{tabular}{|c|c|c|c|c|c|}
\hline Population & Line & Plant Height (cm) & Culm Length (cm) & Panicle Length (cm) & No. of Tillers \\
\hline \multirow{2}{*}{ Parent } & Samgwang & $109.8 \pm 1.65 \S$ & $88.7 \pm 2.24$ & $18.4 \pm 0.16$ & $13 \pm 0.80$ \\
\hline & Seolgaeng & $106.0 \pm 0.12$ & $84.4 \pm 1.36$ & $19.0 \pm 0.55$ & $10 \pm 0.98$ \\
\hline \multirow{7}{*}{$\mathrm{BC}_{2} \mathrm{~F}_{2}$} & SS50-25 & $108.3 \pm 0.62$ & $88.6 \pm 0.10$ & $18.5 \pm 0.45$ & $11 \pm 1.96$ \\
\hline & SS50-26 & $104.8 \pm 0.41$ & $85.0 \pm 1.25$ & $16.7 \pm 0.24$ & $10 \pm 0.50$ \\
\hline & SS50-27 & $109.3 \pm 0.62$ & $90.8 \pm 0.99$ & $17.4 \pm 0.50$ & $13 \pm 1.41$ \\
\hline & SS50-28 & $110.8 \pm 1.74$ & $88.4 \pm 1.51$ & $19.5 \pm 0.53$ & $13 \pm 0.94$ \\
\hline & SS29-06 & $112.6 \pm 0.66$ & $94.5 \pm 2.02$ & $18.4 \pm 0.10$ & $12 \pm 1.50$ \\
\hline & SS29-12 & $112.8 \pm 0.45$ & $92.8 \pm 0.91$ & $18.0 \pm 0.20$ & $12 \pm 0.82$ \\
\hline & $F$-value & $5.28 * *$ & $7.98 * * *$ & $5.31^{* *}$ & 1.23 \\
\hline
\end{tabular}

\section{Discussion}

Rice analysis using an RVA profile can characterize changes in physicochemical properties of rice during starch kneading and show a significant correlation with meal quality $[43,44]$. The RVA profile is closely related to the amylose content and diet in rice $[45,46]$. The elements of an RVA profile such as breakdown viscosity and setback viscosity can reflect the cooking and eating quality differences between rice varieties [47], and can also be used as an auxiliary means to evaluate the quality of rice intake [48,49]. Wu et al. [50] revealed that the soluble starch synthase gene SSIIa has a significant influence on the RVA profile properties of glutinous rice. Previous studies have shown that the cooking and eating quality of rice is regulated by other genes related to starch synthesis in addition to the Wx gene. Tian et al. [44] revealed that SSIIa affects amylose content, gel consistency, and gelatinization temperature, and SSI, SSIIIa, AGPase, and PUL also affect amylose content by association analysis.

The degree of cooking of rice grain with different degrees of milling showed that the aleurone layer affects the degree of rice cooking, including factors such as optimum cooking time and water absorption, as well as affecting texture profile features such as hardness, adhesiveness, paste profile, and characteristics of viscosity [51-53]. However, rice grain has an uneven surface, making it difficult to remove the aleurone layer by mechanical milling [54,55]. SS2, encoded by the Sus-1 gene in maize, is mainly expressed in the aleurone layers and the embryo. Some SS2 proteins are also detected in endosperm tissues, but are mainly localized at low levels in the crown region and basal transfer cells [56,57]. Similarly, in situ hybridization experiments show that SS1 RNA mainly accumulates in the endosperm tissues except for the aleurone layer, whereas SS2 RNA accumulates in the aleurone layer and the embryo [58].

Therefore, SNP markers for foreground selection were identified to improve edibility and processability through SNP mapping of Samgwang and Seolgaeng with SSIIa as a target gene in this study. Line selection according to the genotype of the KASP marker was successful in $\mathrm{BC}_{1} \mathrm{~F}_{1}$ and $\mathrm{BC}_{2} \mathrm{~F}_{1}$ generations with a recurrent parent genome recovery ratio ranging from $91.22 \%$ to $98.65 \%$. We applied SNP markers to shorten the breeding cycle for background selection with the KASP markers. SNPs for KASP markers related to cooking and eating quality were discovered through genome mapping after whole genome re-sequencing analysis. The conventional backcrossing process takes six to seven generations or more, but the MABc system can shorten the breeding cycle to three to four generations or fewer, thereby reducing the number of breeding cycles [59]. It has been successfully applied to various crops such as rice, soybean, and rye, and has successfully contributed to the development of new varieties [22]. Currently, KASP analysis is being used in various crops due to its low cost and locus specificity and efficiency [60].

In this study, 397 polymorphic markers were identified out of 773 KASP markers tested in both parents. As a result of final analysis with 397 KASP markers for background selection analysis, 96 KASP markers were selected with an interval of about $5 \mathrm{Mb}$ per 
chromosome and were evenly distributed across 12 rice chromosomes. The recurrent parent genome recovery ratio was analyzed using 96 markers. Twenty-five lines with recurrent parent genome recovery ratios in the range $91.22-98.65 \%$ were selected, and finally, six lines with excellent phenotypes in $\mathrm{BC}_{2} \mathrm{~F}_{1}$ were selected. In our investigation of agricultural traits, most traits were identified to recover the traits of Samgwang well due to a high genomic recovery ratio through backcrossing of Samgwang and Seolgaeng. In $\mathrm{BC}_{2} \mathrm{~F}_{1}$ seeds of the selected lines, thicknesses of the seed coat and aleurone layer were found to range from 13.82 to $21.67 \mu \mathrm{m}$, suggesting that selection by MABc could be used for developing softer chewing characteristics of rice varieties. Since this study performed $\mathrm{MABc}$ on $\mathrm{BC}_{1} \mathrm{~F}_{1}$ and $\mathrm{BC}_{2} \mathrm{~F}_{1}$ lines in the early generation of backcross breeding, the best performing rice lines were selected in a relatively short breeding cycle. We believe that the seed coat and aleurone layer thickness mutant lines for better eating quality and processability can be used as new breeding materials to develop softer and high-quality rice varieties in rice breeding programs.

\section{Conclusions}

Consumers prefer to have high eating quality rice with high nutrients. Brown rice is rich in nutrients such as protein, dietary fiber, and vitamins. However, the rice bran layer is thicker than that of white rice and the texture of the rice is somewhat rough because moisture absorption is poor due to the difference in structural characteristics. In this study, we aimed to breed new rice lines with a thinner seed coat and aleurone layer to provide high eating quality with softer chewing characteristics and processability in rice grain by applying marker-assisted backcrossing (MABc) breeding programs to backcross populations between Samgwang and Seolgaeng using KASP markers.

As a result, we selected six lines that were detected to range from 13.82 to $21.67 \mu \mathrm{m}$ in thickness of the aleurone layer, which is much thinner than the $30.91 \mu \mathrm{m}$ of the wild type. These lines will be useful to develop new brown rice varieties with softer chewing characteristics and processability in rice grain.

Author Contributions: Experimental analysis and writing article, M.-S.K. and J.-K.Y.; investigation, S.-R.K. and K.-J.K.; methodology, H.J.; idea development and review, K.-K.K.; funding, supervision, idea development, and editing, Y.-G.C. All authors have read and agreed to the published version of the manuscript.

Funding: This work was funded by a grant from the Next-Generation Biogreen 21 Program (The Agricultural Genome Center, PJ01330201), Rural Development Administration, Republic of Korea.

Institutional Review Board Statement: Not applicable.

Informed Consent Statement: Not applicable.

Data Availability Statement: Not applicable.

Acknowledgments: This work was supported by a grant from the Next-Generation Biogreen 21 Program (The Agricultural Genome Center, PJ01330201), Rural Development Administration, Republic of Korea.

Conflicts of Interest: The authors have no conflict of interest relevant to this study to disclose.

\section{References}

1. Rohit, R.; Parmar, K. Unified approach in food quality evaluation using machine vision. Commun. Comput. Inf. Sci. 2011, 192, 239-248.

2. Aluko, G.; Martinez, C.; Tohme, J.; Castano, C.; Bergman, C.; Oard, J.H. QTL mapping of grain quality traits from the interspecific cross Oryza sativa x O. glaberrima. Appl Genet. 2004, 109, 630-639. [CrossRef] [PubMed]

3. Rabiei, B.; Valizadeh, M.; Ghareyazie, B.; Moghaddam, M.; Ali, A. Identification of QTLs for rice grain size and shape of Iranian cultivars using SSR markers. Euphytica 2004, 137, 325-332. [CrossRef]

4. Chen, H.; Siebenmorgen, T.J.; Griffin, K. Quality Characteristics of Long-Grain Rice Milled in Two Commercial Systems. Cereal Chem. 1998, 75, 560-565. [CrossRef] 
5. Krishna, A.G.; Khatoon, S.; Shiela, P.M.; Sarmandal, C.V.; Indira, T.N.; Mishra, A. Effect of refining of crude RBO on the retention of oryzanol in the refined oil. J. Am. Oil Chem. Soc. 2001, 78, 127-131. [CrossRef]

6. Moon, G.S.; Kim, M.; Jin, M.; Kim, S.; Park, S.; Ryu, B. Physicochemical and Sensory Properties of Rice Stored in an Un-used Tunnel. Korean J. Food Cook. Sci. 2010, 26, 220-228.

7. Tran, T.U.; Suzuki, K.; Okadome, H.; Homma, S.; Ohtsubo, K. Analysis of the tastes of brown rice and milled rice with different milling yields using a taste sensing system. Food Chem. 2004, 88, 557-566. [CrossRef]

8. Heiniö, R.L.; Noort, M.W.J.; Katina, K.; Alam, S.A.; Sozer, N.; de Kock, H.L.; Hersleth, M.; Poutanen, K. Sensory characteristics of wholegrain and bran-rich cereal foods-A review. Trends Food Sci. Technol. 2016, 47, 25-38. [CrossRef]

9. Mir, S.A.; Shah, M.A.; Bosco, D.S.J.; Sunooj, K.V.; Farooq, S. A review on nutritional properties, shelf life, health aspects and consumption of brown rice in comparison with white rice. Cereal Chem. 2020, 97, 895-903. [CrossRef]

10. Zhang, G.; Malik, V.S.; Pan, A.; Kumar, S.; Holmes, M.D.; Spiegelman, D.; Lin, X.; Hu, F.B. Substituting Brown Rice for White Rice to Lower Diabetes Risk: A Focus-Group Study in Chinese Adults. J. Am. Diet. Assoc. 2010, 110, 1216-1221. [CrossRef]

11. Choi, I.S.; Ahn, S.N.; Baek, M.K.; Yang, C.I.; Yang, S.J.; Hong, H.C.; Moon, H.P.; Choi, H.C.; Hwang, H.G.; Kim, Y.G.; et al. New Cultivar Developed: A Lodging Tolerant, Opaque Rice Cultivar "Seolgaeng". Korean J. Breed. Sci. 2011, 43, 532-537.

12. Choi, H.C.; Hong, H.G.; Kim, Y.G.; Kim, H.Y.; Yea, J.D.; Shin, Y.S.; Kang, K.H.; Song, M.T.; Choi, Y.H.; Cho, Y.C.; et al. A japonica specialty rice for fermentation food processing, opaque rice cultivar "Seolgaeng". Treat Crop Res. 2002, 3, 45-51.

13. Kang, H.J.; Han, H.S.; Hwang, I.K. Comparison of gelatinization and retrogradation characteristics among endosperm mutant rices derived from Ilpumbyeo. Korean J. Food Sci. Technol. 2004, 36, 879-884.

14. Kim, K.J.; Woo, K.S.; Lee, J.S.; Chun, A.; Yoon, H.C.; Song, J.; Suh, S.J.; Kim, S.L.; Jeong, H.S. Physicochemical characteristics of Sikhye (Korean Traditional Rice Beverage) with specialty rice varieties. J. Korean Soc. Food Sci. Nutr. 2008, 37, 1523-1528. [CrossRef]

15. Sundaram, R.M.; Vishnupriya, M.R.; Biradar, S.; Laha, G.S.; Reddy, G.A.; Rani, N.S.; Sarma, N.P.; Sonti, R.V. Marker assisted introgression of bacterial blight resistance in Samba Mahsuri, an elite indica rice variety. Euphytica 2007, 160, 411-422. [CrossRef]

16. Suh, J.-P.; Jeung, J.-U.; Noh, T.-H.; Cho, Y.-C.; Park, S.-H.; Park, H.-S.; Shin, M.-S.; Kim, C.-K.; Jena, K.K. Development of breeding lines with three pyramided resistance genes that confer broad-spectrum bacterial blight resistance and their molecular analysis in rice. Rice 2013, 6, 1-11. [CrossRef]

17. Collard, B.C.; Vera Cruz, C.; McNally, K.L.; Virk, P.S.; Mackill, D.J. Rice Molecular Breeding Laboratories in the Genomics Era: Current Status and Future Considerations. Int. J. Plant Genom. 2008, 2008, 524847. [CrossRef]

18. Frisch, M.; Melchinger, A.E. Selection theory for marker-assisted back-crossing. Genetics 2005, 170, 909-917. [CrossRef]

19. Chen, S.; Xu, C.G.; Lin, X.H.; Zhang, Q. Improving bacterial blight resistance of ' 6078 ', an elite restorer line of hybrid rice, by molecular marker-assisted selection. Plant Breed. 2001, 120, 133-137. [CrossRef]

20. Chen, Z.W.; Guan, H.Z.; Wu, W.R.; Zhou, Y.C.; Han, Q.D. The screening of molecular markers closely linked to rice blast-resistant gene Pi-1 and their application. J. Fujian Agric. Forest. Univ. 2005, 34, 74-77.

21. McCouch, S.R.; Zhao, K.; Wright, M.; Tung, C.-W.; Ebana, K.; Thomson, M.; Reynolds, A.; Wang, D.; De Clerck, G.; Ali, L.; et al. Development of genome-wide SNP assays for rice. Breed. Sci. 2010, 60, 524-535. [CrossRef]

22. Neelam, K.; Brown-Guedira, G.; Huang, L. Development and validation of a breeder-friendly KASPar marker for wheat leaf rust resistance locusLr21. Mol Breed. 2013, 31, 233-237. [CrossRef]

23. Shi, Z.; Liu, S.; Noe, J.; Arelli, P.; Meksem, K.; Li, Z. SNP identification and marker assay development for high-throughput selection of soybean cyst nematode resistance. BMC Genom. 2015, 16, 314. [CrossRef] [PubMed]

24. Lee, J.; Won, Y.J.; Cho, Y.; Lee, J.H.; Yang, C.; Kim, M.; Ahn, E.; Suh, J.P.; Lee, S.; Jeon, Y.H.; et al. 'Samkwang1', a Medium Maturing, Multiple Disease Resistant, and High-quality Rice. Korean J. Breed. Sci. 2018, 50, 490-496. [CrossRef]

25. Rural Development Administration (RDA). Standard of Analysis and Survey for Agricultural Research; RDA: St. Joseph, MO, USA, 2012; pp. 315-338.

26. Nogoy, F.M.; Jung, Y.J.; Kang, K.K.; Cho, Y.-G. Characterization of 'GolSam' Lines Developed from the Cross between Samgwang and 5MT Resistant Lines in Rice. Plant Breed. Biotechnol. 2018, 6, 233-244. [CrossRef]

27. Osborne, B.G. Near-Infrared Spectroscopy in Food Analysis. Encycl. Anal. Chem. 2006. [CrossRef]

28. Kim, C.-E.; Kang, M.-Y.; Kim, M.-H. Comparison of Properties Affecting the Palatability of 33 Commercial Brands of Rice. Korean J. Crop. Sci. 2012, 57, 301-309. [CrossRef]

29. Chi, X.; Zhang, Y.; Xue, Z.; Feng, L.; Liu, H.; Wang, F.; Qi, X. Discovery of rare mutations in extensively pooled DNA samples using multiple target enrichment. Plant Biotechnol. J. 2014, 12, 709-717. [CrossRef]

30. Cheon, K.S.; Baek, J.H.; Cho, Y.I.; Jeong, Y.M.; Lee, Y.Y.; Jun, O.; Won, Y.J.; Kang, D.Y.; Oh, H.J.; Kim, S.L.; et al. Single Nucleotide Polymorphism (SNP) Discovery and Kompetitive Al-lele-Specific PCR (KASP) Marker Development with Korean Japonica Rice. Plant Breed. Biotech. 2018, 6, 391-403. [CrossRef]

31. Park, H.-S.; Lee, K.-M.; Kim, K.-Y.; Kim, J.-J.; Shin, W.-C.; Baek, M.-K.; Kim, C.-S.; Park, S.-G.; Lee, C.-M.; Suh, J.-P.; et al. Development of Near-Isogenic Line of japonica Rice Cultivar Saenuri without Lipoxygenase-3. Korean J. Breed. Sci. 2019, 51, 190-200. [CrossRef]

32. Carlo, P.; Marco, B. Histochemistry of Single Molecules: Methods and Protocols, Methods in Molecular Biology; Humana Press: Totowa, NJ, USA, 2017; p. 1560. 
33. Kim, W.S.; Shin, M. The properties of rice flours prepared by dry- and wet-milling of soaked glutinous and normal grains. Korean J. Food Cookery Sci. 2007, 23, 908.

34. Lin, L.; Lu, F.; Chang, Y. Prediction of protein content in rice using a near-infrared imaging system as diagnostic technique. Int. J. Agric. Biol. Eng. 2019, 12, 195-200.

35. Lestari, P.; Lee, G.; Ham, T.H.; Woo, M.O.; Piao, R.; Jiang, W.; Chu, S.H.; Lee, J.H.; Koh, H.J. Single Nucleotide Poly-morphisms and Haplotype Diversity in Rice Sucrose Synthase 3. J. Hered. 2011, 102, 735-746. [CrossRef] [PubMed]

36. Lee, K.J.; Lee, S.Y.; Kim, Y.R.; Park, J.W.; Shim, J.Y. Effect of dry heating on the pasting/retrogradation and textural properties of starch-soy protein maxture. Korean J. Food Sci. Technol. 2004, 36, 568-573.

37. Kwakt, T.S. Comparison of Amylogram Properties among Several Subspecies of Rice. Korean J. Crop Sci. 2005, 50, 186-190.

38. Lee, H.-M.; Lee, Y.-T. Pasting Properties of Corn, Potato, Sweet Potato Starches and Wheat Flours with Partial Rice Starch Substitution. Food Eng. Prog. 2013, 17, 238-244. [CrossRef]

39. Shafie, B.; Cheng, S.C.; Lee, H.H.; Yiu, P.H. Characterization and classification of whole-grain rice based on rapid visco analyzer (RVA) pasting profile. Int. Food Res. J. 2016, 23, 2138-2143.

40. Oh, S.-K.; Kim, D.-J.; Ryu, S.-J.; Chun, A.-R.; Yoon, M.-R.; Choi, I.-S.; Hong, H.-C.; Kim, Y.-K. Quality Characteristics of Korean Traditional Wine Using Seolgaengbyeo for Brewing Rice. J. Korean Soc. Food Sci. Nutr. 2011, 40, 1189-1194. [CrossRef]

41. Sung, J.; Lee, J.; Oh, S.K.; Lee, J.S.; Choi, W.S. Changes in Phytochemical Content and Antiproliferative Activity of Germinated Geunnun and Ilpum Rice Varieties. J. Korean Soc. Food Sci. Nutr. 2013, 42, 1157-1161. [CrossRef]

42. Van Rayne, K.K.; Adebo, O.A.; Ngobese, N.Z. Nutritional and Physicochemical Characterization of Strychnos mada-gascariensis Poir (Black Monkey Orange) Seeds as a Potential Food Source. Foods 2020, 9, 1060. [CrossRef]

43. Lee, H.; Kim, H.-S. Pasting and paste properties of waxy rice starch as affected by hydroxypropyl methylcellulose and its viscosity. Int. J. Biol. Macromol. 2019, 153, 1202-1210. [CrossRef] [PubMed]

44. Bao, J.; Kong, X.; Xie, J.; Xu, L. Analysis of Genotypic and Environmental Effects on Rice Starch. 1. Apparent Amylose Content, Pasting Viscosity, and Gel Texture. J. Agric. Food Chem. 2004, 52, 6010-6016. [CrossRef] [PubMed]

45. Devraj, L.; Natarajan, V.; Vadakkeppulpara, S.; Manicakam, L.; Sarvanan, S. Influence of microwave heating as accelerated aging on physicochemical, texture, pasting properties and microstructure in brown rice of selected Indian rice varieties. J. Texture Stud. 2020, 51, 663-679. [CrossRef] [PubMed]

46. Thanyasiriwat, T.; Sraphet, S.; Whankaew, S.; Boonseng, O.; Bao, J.; Lightfoot, D.; Tangphatsornruang, S.; Triwitayakorn, K Quantitative trait loci and candidate genes associated with starch pasting viscosity characteristics in cassava (Manihot esculenta Crantz). Plant Biol. 2013, 16, 197-207. [CrossRef]

47. Bason, M.L.; Blakeney, A.B. Grain and grain products. In The RVA Handbook; Crosbie, G.B., Ross, A.S., Eds.; American Association of Cereal Chemists International: St. Paul, MN, USA, 2007; pp. 31-47.

48. Su, W.L.; Xiang, X.C.; Xu, Y.F.; Long, X.L.; Kang, C.F.; Xu, S.J. The influence of gene soluble starch synthase II a gene (SSII-3) on rice starch viscosity (RVA profile) in non-glutinous rice (Oryza sativa ssp. indica). J. Agric. Biotechnol. 2014, 22, 289-297.

49. Chen, S.Q.; Xu, Q.F.; Pan, G.J.; Wang, Q.Y. Relationship between RVA profile characteristics and other quality traits in grain positions of Japonica rice. J. Nucl. Agric. Sci. 2015, 29, 0244-0251.

50. Wu, H.K.; Liang, G.H.; Gu, Y.J.; Shang, L.L.; Wang, F.; Han, Y.P.; Gu, M.H. The effect of the starch-synthesizing genes on RVA profile characteristics in rice (Oryza sativa L.). Acta Agron. Sin. 2006, 32, 159-163.

51. Mohapatra, D.; Bal, S. Cooking quality and instrumental textural attributes of cooked rice for different milling fractions. J. Food Eng. 2006, 73, 253-259. [CrossRef]

52. Saleh, M.I.; Meullenet, J.-F. Effect of Moisture Content at Harvest and Degree of Milling (Based on Surface Lipid Content) on the Texture Properties of Cooked Long-Grain Rice. Cereal Chem. 2007, 84, 119-124. [CrossRef]

53. Yoon, S.H.; Kim, S.K. Physicochemical properties of rice differing in milling degrees. Food Sci. Biotechnol. 2004, $13,57-62$.

54. Mohapatra, D.; Bal, S. Effect of degree of milling on specific energy consumption, optical measurements and cooking quality of rice. J. Food Eng. 2007, 80, 119-125. [CrossRef]

55. Wood, D.F.; Siebenmorgen, T.J.; Williams, T.G.; Orts, W.J.; Glenn, G.M. Use of microscopy to assess bran removal patterns in milled rice. J. Agric. Food Chem. 2012, 60, 6960-6965. [CrossRef] [PubMed]

56. Chen, Y.C.; Chourey, P.S. Spatial and temporal expression of the two sucrose synthase genes in maize: Immunohistological evidence. Theor. Appl. Genet. 1989, 78, 553-559. [CrossRef] [PubMed]

57. Heinlein, M.; Starlinger, P. Tissue- and cell-specific expression of the two sucrose synthase isoenzymes in developing maize kernels. Mol. Genet. Genom. 1989, 215, 441-446. [CrossRef]

58. Rowland, L.J.; Chourey, P.S. In situ hybridization analysis of sucrose synthase expression in developing kernels of maize. Maydica 1990, 35, 373-382.

59. Hasan, M.M.; Rafii, M.Y.; Ismail, M.R.; Mahmood, M.; Rahim, H.A.; Alam, M.A.; Ashkani, S.; Malek, M.A.; Latif, M.A. Markerassisted backcrossing: A useful method for rice improvement. Biotechnol. Biotechnol. Equip. 2015, 29, 237-254. [CrossRef]

60. Kumpatla, S.P.; Buyyarapu, R.; Abdurakhmonov, I.Y.; Mammadov, J. Genomics-Assisted Plant Breeding in the 21st Century: Technological Advances and Progress. Sci. Acad. Pap. Collect. 2012. [CrossRef] 